\title{
RELIABILITY AND SAFETY OF MINE HOIST INSTALLATIONS
}

\section{NIEZAWODNOŚC I BEZPIECZEŃSTWO GÓRNICZYCH WYCIĄGÓW SZYBOWYCH}

\author{
Józef Hansel \\ AGH University of Science and Technology in Krakow (AGH-UST), \\ Faculty of Technical Engineering and Robotics, Department of Rope Transport \\ e-mail:hansel@agh.edu.pl
}

\begin{abstract}
In recent years the required working conditions and safety features of the vertical transport systems in Polish collieries have been achieved through enhanced supervision and control and by prolonged repairs, diagnostics and maintenance procedures aimed to ensure the satisfactory performance levels of hoisting installations This approach to reliability and safety of transport systems, which ought to be treated as intricate anthropotechnic systems, result in an increased risk of life loss and injury of maintenance personnel and hoist operators. This paper is limited in scope and focuses on selected aspects:

- identification of the problem of reliability and safety of the hoisting systems,

- identification of causes of catastrophic failures,

- summary of major research data,

- list of methods, means and solutions developed at AGH-UST to improve the safety of hoisting installations.
\end{abstract}

Key Words: safety, mine hoist instalations

Streszczenie: $W$ ostatnich kilkunastu latach $w$ polskich kopalniach podziemnych wymagany przepisami prawa górniczego stan techniczny systemów maszynowych transportu pionowego oraz poziom bezpieczeństwa tych systemów byt osiagany głównie przez zwiększenie nadzoru $i$ kontroli oraz przedtużenie czasów przeznaczonych na remonty, naprawy, diagnozowanie i inne czynności zwiazane z odnowa potencjału eksploatacyjnego elementów górniczych wyciagów szybowych.

Ten sposób rozwiazywania problemów utrzymywania określonych zdolności transportowych szybów oraz niezawodności i bezpieczeństwa, spowodowat wzrost ryzyka utraty życia $i$ zdrowia osób zajmujących się procesami obstugiwania górniczych wyciagów szybowych. W tej publikacji:

- sformułowano problem niezawodności i bezpieczeństwa górniczych wyciagów szybowych,

- przedstawiono wyniki analiz $i$ ocen przyczyn oraz skutków uszkodzeń typu katastroficznego elementów górniczych wyciagów szybowych,

- zamieszczono końcowe wyniki prac naukowo-badawczych AGH-UST,

- wymieniono opracowane w AGH-UST metody, sposoby $i$ środki techniczne, których stosowanie już przyczynia się do poprawy bezpieczeństwa górniczych wyciagów szybowych.

Stowa kluczowe: bezpieczeństwo, górnicze wyciagi szybowe 


\section{Introduction}

In recent years the required working conditions and safety features of the vertical transport systems in Polish collieries have been achieved through enhanced supervision and control and by prolonged repairs, diagnostics and maintenance procedures aimed to ensure the satisfactory performance levels of hoisting installations.

This approach to reliability and safety of transport systems, which ought to be treated as intricate anthropotechnic systems, result in an increased risk of life loss and injury of maintenance personnel and hoist operators. The risk for hoist operators is decidedly greater than of operators of other machines used in other sectors.

The methodology outlined in this study was developed by the Department of Ropeway Installations AGH-UST in collaboration with the State Mining Authority in Katowice to improve the safety features. The methodology involves:

- system for management of hoist safety in Polish collieries,

- methods and means to improve the safety standards in vertical transport,

- computer-assisted system supporting the safety management system,

- database of currently operated hoisting installations in Poland,

- methodology to control the occupation hazard of hoist operators,

- professional and on-the-job training (I and II degree programs, postgraduate studies, specialist training) for those engaged in design, engineering, diagnostics, maintenance and operation of hoisting installations.

This paper is limited in scope and focuses on selected aspects:

- identification of the problem of reliability and safety of the hoisting systems,

- identification of causes of catastrophic failures,

- summary of major research data,

- list of methods, means and solutions developed at AGH-UST to improve the safety of hoisting installations.

\section{Reliability and safety of anthropotechnic systems}

Safety of technical objects is closely associated with reliability of anthropotechnic systems and might be solved using the methods of the reliability theory. No matter what the actual cause, technical part of the system might fail and an operator might make a mistake, which creates a potentially risky situation. 
The analysis of reliability of a technical object focuses on breakdowns, machine failures and human mistakes, whereas the work safety is mostly concerned with those failures and errors that might lead to situations where extra effort is required to avert the danger (an accident, catastrophe).

It is apparent that the theory of reliability and that of safety are closely linked, the theory of reliability emphasises the machine failures and human errors whereas the theory of safety concentrates on potential hazards to humans and environment.

Starting from the study of the effects, the theory of safety deals with failures and human errors that might endanger human life and health and the natural environment. Broadly speaking, these are mainly caused by:

- unfavourable surroundings,

- human errors (hoist operators, signal men, repairmen) during the hoist operation caused by illness, stress, insufficient training, lack of attention, neglect,

- faulty operation of machines, signalling systems, control systems and other functional facilities.

\section{Analysis of causes and effects of catastrophic failures of hoisting installations in polish mines}

The analysis of statistical data reveals that operation of hoisting installations might be treated as Markov's stochastic processes. The Markov process can be assumed under the following assumptions:

- failures of hoisting elements components should be treated as independent random events,

- probability of failure in all nearly identical system components should be the same,

- operation and maintenance processes are subject to the exponential reliability principle.

The adequacy of those assumption was verified accordingly by:

- checking the independent character of particular service conditions of the system elements,

- investigation of a cyclic component,

- checking the homogeneity of operational test data,

- checking the distribution of particular service condition times [2].

Identification of the hoisting installations elements, application of the Markov's stochastic model to their description and verification of the model adequacy supported by extensive statistical data permits a reliable 
evaluation of causes and effects of catastrophic and parametric failures of the system. Application of the Markov's model allows the numerical factors to be computed easily. These indicators are treated as the measure of reliable safety (for catastrophic failures) or parametric reliability given by formulas below.

Intensity of failure occurrence $\lambda$ :

$$
\lambda=\frac{1}{T_{P}} \quad[1 / \mathrm{h}]
$$

where:

$$
T_{P}=\frac{\sum_{i=1}^{n} T_{P i}}{n} \quad[\mathrm{~h}]
$$

$T_{P} \quad$ - average time of correct operation in [h],

$T_{P i} \quad$ - periods of correct operation between the subsequent catastrophic or parametric failures in $[\mathrm{h}]$, $n-$ number of failures,

Intensity of failure decay $\beta$ :

$$
\beta=\frac{1}{T_{A}}
$$

where:

$$
T_{A}=\frac{\sum_{i=1}^{n} T_{A i}}{n} \quad[\mathrm{~h}]
$$

$T_{A} \quad$ - average shutdown time due to the failure [h],

$T_{A i} \quad$ - shutdown times due to failures,

$\chi$ - failure occurrence factor $\chi$ :

$$
\chi=\frac{\lambda}{\beta}
$$

Critical probability of correct operation $P_{P}$

$$
P_{P}=\frac{\beta}{\lambda+\beta}
$$

Critical probability of a failure

$$
P_{A}=\frac{\lambda}{\lambda+\beta}
$$

Numerical values of these indicators can be computed on the basis of source data: failure and accident reports available from the State Mining Authority 
(for catastrophic failures) and the records documenting the shaft operations available at the mining companies.

Catastrophic failures include all unplanned shutdowns of hoisting installations, registered by the State Mining Authority. These shutdowns, lasting for more than 8 hours, are mainly the consequence of overwind travels, broken hoisting or balance ropes, conveyance falling into the shaft. Such failures always involve considerable material loss, ranging from several hundred to several million EURO and present a major threat to human life and health.

Statistical analysis covered all hoisting installations in mines (over the period of more than ten years), with the conveyance capacity no less than $7,5 \mathrm{Mg}$, operated in mines where the novel solutions developed at AGHUST have not been implemented yet. These solutions, listed in section 5, vastly improve the hoisting safety.

Table 1 summarises the reliability indicators for particular types of catastrophic failures, obtained for hoisting installations in collieries. "Other failures" include infrequent failures, for instance due to the damage of the headframe structure or shaft steelwork. The shutdown time in case of such failures will be long, so though their proportion is rather small, the shutdown time they produce can be still considerable.

Table 1. Reliability indicators for particular types of catastrophic failures

\begin{tabular}{|l|l|c|c|c|c|c|}
\hline \multirow{2}{*}{ Lp. } & \multicolumn{1}{|c|}{ Failure } & \multicolumn{5}{|c|}{ Reliability indicator } \\
\cline { 3 - 7 } & $\begin{array}{c}T_{A} \\
{[\mathrm{~h}]}\end{array}$ & $\begin{array}{c}T_{P} \\
{[\mathrm{~h}]}\end{array}$ & $\begin{array}{c}\lambda \times 10^{-5} \\
{[1 / \mathrm{h}]}\end{array}$ & $\begin{array}{c}\beta \\
{[1 / \mathrm{h}]}\end{array}$ & $\chi \times 10^{-3}$ \\
\hline 1. & Overwind travels & 43,0 & 151053,6 & 0,662 & 0,023 & 0,285 \\
\hline 2. & Winder failure & 37,5 & 169485,3 & 0,590 & 0,027 & 0,221 \\
\hline 3. & $\begin{array}{l}\text { Power failure (electric } \\
\text { power cut) }\end{array}$ & 4,4 & 217195,7 & 0,460 & 0,227 & 0,020 \\
\hline 4. & $\begin{array}{l}\text { Conveyance or the } \\
\text { material falling to the } \\
\text { shaft bottom }\end{array}$ & 35,6 & 238194,2 & 0,403 & 0,028 & 0,143 \\
\hline 5. & $\begin{array}{l}\text { Entangled, broken or } \\
\text { deformed hoisting rope }\end{array}$ & 38,3 & 365774,2 & 0,273 & 0,026 & 0,105 \\
\hline 6. & $\begin{array}{l}\text { Breakdown of the } \\
\text { guiding system }\end{array}$ & 24,8 & 386109,9 & 0,259 & 0,040 & 0,064 \\
\hline 7. & Broken balance rope & 30,6 & 408818,3 & 0,245 & 0,033 & 0,075 \\
\hline 8. & Conveyance failure & 19,8 & 579181,8 & 0,173 & 0,050 & 0,034 \\
\hline 9. & Pulley failure & 9,5 & 868791,7 & 0,115 & 0,105 & 0,011 \\
\hline 10. & Other failures & 139,7 & 992794,6 & 0,101 & 0,007 & 0,141 \\
\hline
\end{tabular}


where: $T_{A}$ - average shutdown time,

$T_{P}-$ average time of correct operation,

$\lambda$ - intensity of failure occurrence,

$\beta$-intensity of failure decay,

$\chi$ - failure occurrence factor.

Fig 1 shows the proportions of various types of failures in relation to the total number of catastrophic failures and the shutdown time, Figs 2-6 show the results produced by those failures.

a)

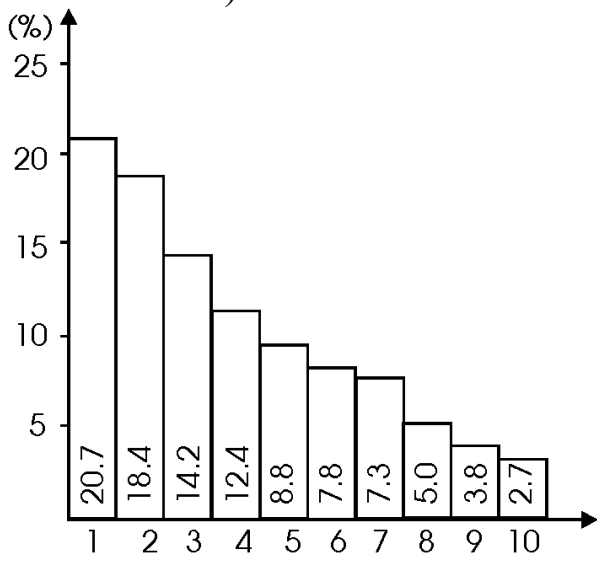

b)

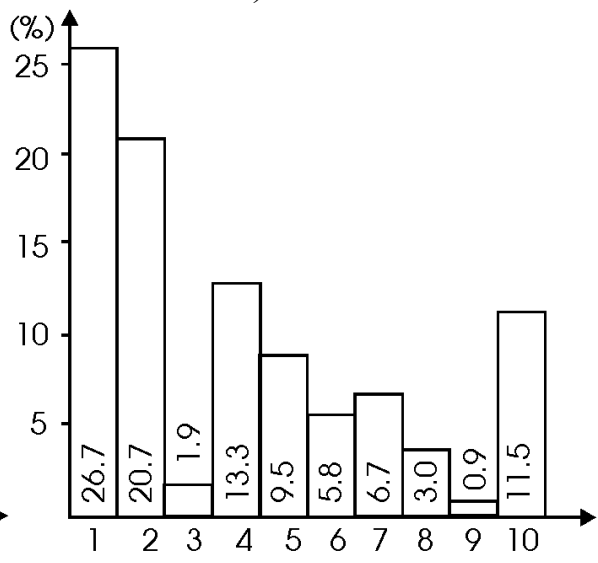

Fig. 1 Proportion of particular types of catastrophic failures: (Failure type) a) in relation to the total number of failures,

b) particular shutdown times in relation to the total shutdown time, where:

1 - overwind travels,

2 - winder failure,

3 - power failure,

4 - conveyance or the material falling to the shaft bottom,

5 - entangled, broken or deformed hoisting rope,

6 - breakdown of the guiding system,

7 - broken balance rope,

8 - conveyance failure,

9 - pulley failure,

10 - other failures 


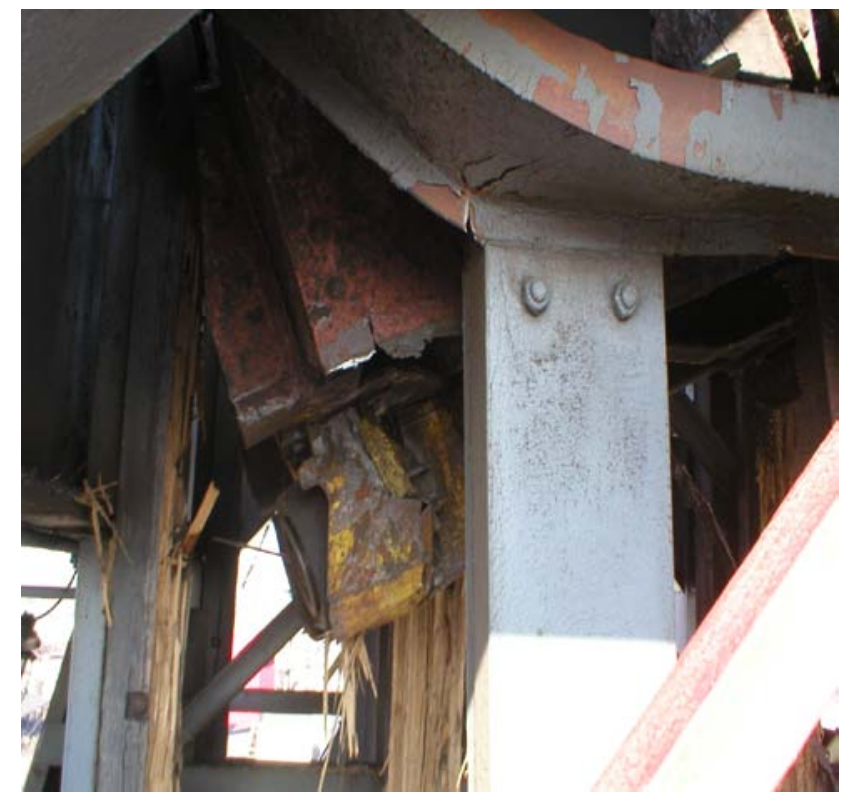

Fig. 2 Effects of overwind travels
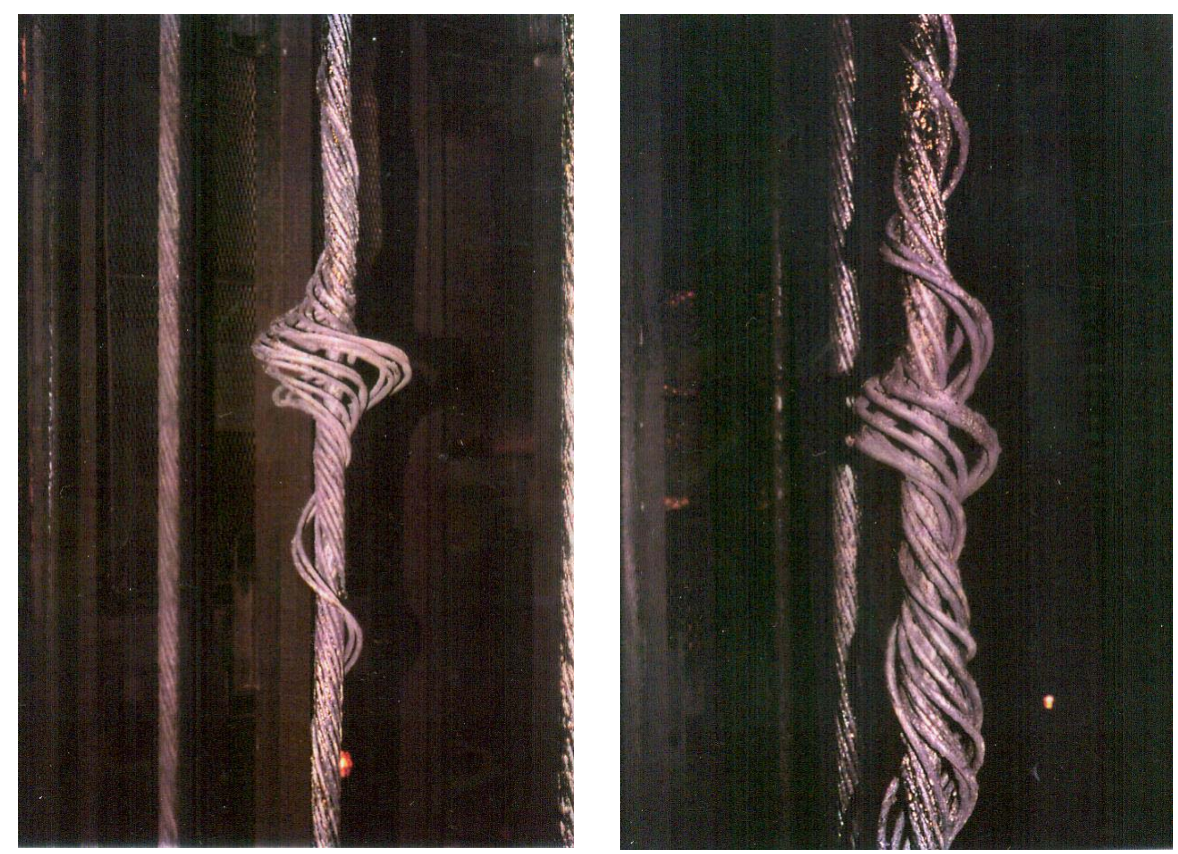

Fig. 3, 4. Damaged balance ropes (round ropes) 

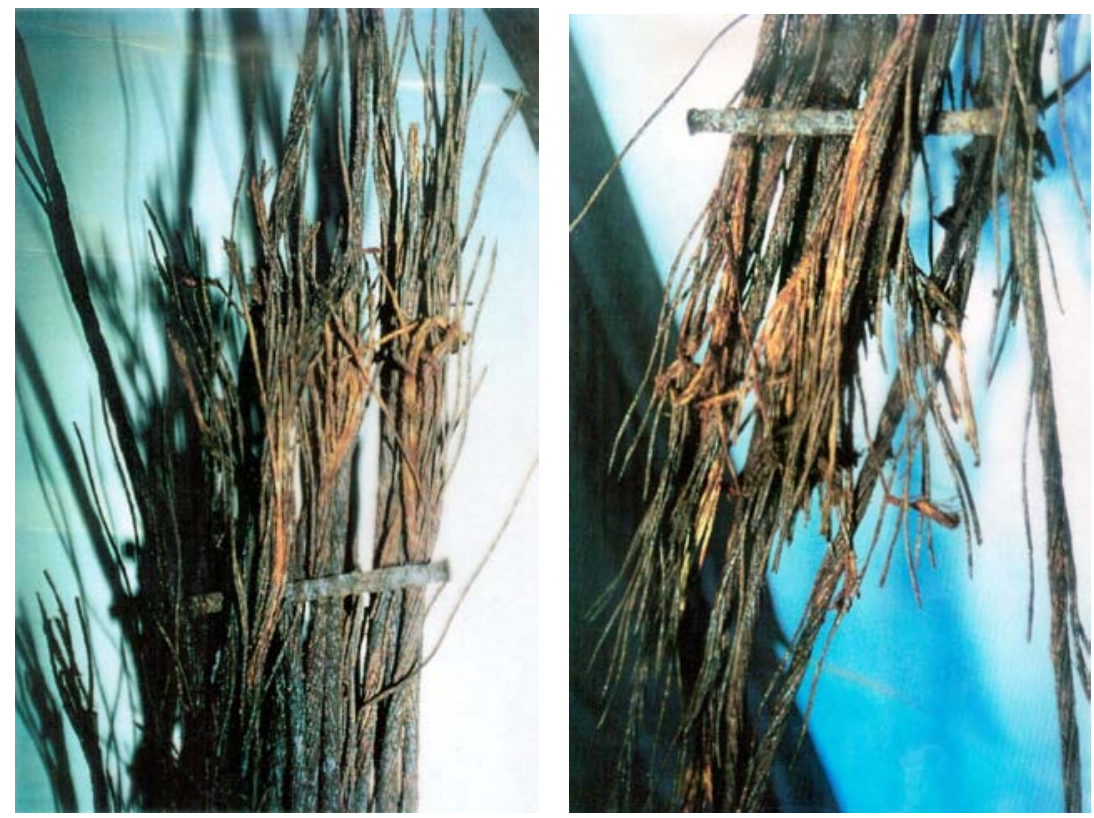

Fig. 5, 6. Broken balance ropes (flat ropes)

\section{Results of research programs pursued at the department of ropeway installations, connected with the new methodology}

The methodology is connected with "my" research program no 4 T12A 016 29 "Development of the methodology for controlling the safety of hoisting installations in Polish collieries". This research program ended in 2009 and so did the program financed through the statutory research fund: "Quality, reliability and safety of ropeway installations" Both projects were sponsored by the Ministry of Science and University Education.

The methodology is supported by the results of research programs and other research data collected at the Department of Ropeway Installations. Extensive research was undertaken under my supervision, covering the issues relating to reliability, safety of anthropotechnic systems and adaptation of the Polish legislature to the EU standards.

In recent years 3 doctoral dissertations have been successfully completed:

1) Agnieszka Wcisło „Development of a nation-wide system to improve the safety of selected installations and the principles of system management", 2000,

2) Adam Zygmunt „Development of a nation-wide system to manage the mine hoist safety", 2004, 
3) Bogusław Chrószcz „Analysis and evaluation of occupational risk of hoist operators in Polish collieries", 2008,

Major research achievements include:

- cause and effect analysis (section 3) of catastrophic failures,

- formulation, definition and starting a public discussion on terms relating to hoist transport safety (safety redundancy, safety level, acceptable risk level),

- identification and definition of 12 types of safety redundancies (structural, functional, parametric, time-related, informational, diagnostic, cognitive, qualitative, systematic margins and those involving resistance features, safety measures and human reliability),

- development of the nation-wide mine hoist safety management system, covering the safety of hoisting operations.

\section{Means and methods to improve the safety of hoisting installations}

Reliability and safety of hoisting installations might be improved through:

- elimination of reducing the probability of a parametric or catastrophic failure occurrence,

- prolonging the service life of ropes, shaft steelwork, conveyances, linings, and hoist components,

- improving the accuracy of diagnostics.

Research data listed above were further utilised to develop more practical solutions, including:

- movable fender beams HWR and a frictional emergency braking system HS2W with the relevant calculation procedure,

- drum and pulley linings designated as modar ${ }^{\circledR}$,

- conveyance guiding system with integrated shock absorbers PHH,

- rubber-coated balance ropes SAG,

- sensor heads for magnetic inspection of wire ropes: GP-60, GP-90 and for inspection of rubber-coated ropes: GP-8, GP-3K200, GP-3K300 [2, 3].

These solutions are the results of many years' research work, right from the formulation of the problem, through conceptual designs of the solution, creation of the mathematical model, laboratory tests, prototyping, legal protection of results, filing the patent applications in Poland and abroad, obtaining the required licences to use, development of the manufacturing technology, serial production, right through to implementation in mines.

All these solutions are protected by 26 patents, 2 patent applications filed in Poland, 4 European patents, others have a status of know-how solutions. 
They were awarded a gold an silver medals at the Inventions, Research and New Technologies Fairs Eureka in Brussels in 2003, 2004, 2005, 2006 (4 gold and 2 solver medals). They won two gold medals at the International Intellectual Property Fair in 2005 and 2007 and a gold medal in Paris in 2007. AGH-UST is the sole proprietor of all these patents and know-how solutions. In the last 5 years the University signed 30 licence agreements allowing their use [3].

\section{Conclusions}

The methodology outlined here is widely adopted in collieries, copper mines and other mining companies, leading to a vast improvement of reliability and safety of the hoisting systems, at the same time permitting the reduction of maintenance and modernisation costs.

\section{References}

1. Ważyńska-Fiok K., Jaźwiński J.: Niezawodność systemów technicznych. PWN Warszawa, 1990

2. Hansel J.: Methodology of improving the safety of mine hoist installations in Poland. Transport \& Logistics 17/09, Belgrad 2009

3. Hansel J.: Wdrożone patenty i rozwiazania know-how jako wyniki prac naukowo-badawczych Katedry Transportu Linowego. Problemy Inżynierii Mechanicznej i Robotyki Nr 40, Kraków 2009

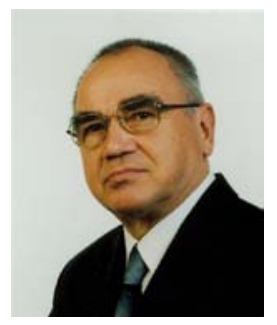

Józef Hansel, Prof. PhD. Eng. professor at the AGH University of Science and Technology, staff the Faculty of Mechanical Engineering and Robotics, director of the Rope Transport Department until 2008 (from 1992). His professional interest is safety problems in engineering with special focusing on rope transport systems and devices. Author or co-author of app. 300 books, papers others scientific publications and consultancy, app. 90 patents including more then 30 outside Poland with their practical application in industry. Past chair of the Laboratory of Rope and Rope Transport Devices Testing AGH UST (1981-92), today chair of the R\&D Laboratory of Transport Devices and Materials AGH UST (from 2006). 